\title{
Clinical and epidemiological characteristics of COVID-19 in children: experience in two hospitals
}

\author{
Jesús J. Martínez-Garciaa,2*, Jesús E. Luna-Méndez ${ }^{2,3}$, David Alarid-Corone/3 ${ }^{3}$ Angélica Lares-Payan², \\ Denih E. Picasso-López², Nidia M. León-Sicairos ${ }^{1,4}$, Juan L. Rochin-Terán ${ }^{5}$, Héctor M. Flores-Villaseñor ${ }^{1,6}$, \\ and Adrián Canizalez-Román ${ }^{1,7}$ \\ ${ }^{1}$ Centro de Investigación Aplicada a la Salud Publica, Facultad de Medicina, Universidad Autónoma de Sinaloa; ${ }^{2}$ Unidad de Terapia Intensiva \\ Pediátrica, Hospital Pediátrico de Sinaloa Rigoberto Aguilar Pico; ${ }^{3}$ Servicio de Pediatría, Hospital General Regional No. 1, Instituto Mexicano del \\ Seguro Social; ${ }^{4}$ Departamento de Investigación, Hospital Pediátrico de Sinaloa Rigoberto Aguilar Pico; ${ }^{5}$ Servicio de Imagenología, Centro de \\ Investigación y Docencia en Ciencias de la Salud, Hospital Civil; ${ }^{6}$ Laboratorio Estatal de Salud Pública del Estado de Sinaloa; ${ }^{7}$ Departamento de \\ Investigación, Hospital de la Mujer SSA. Culiacán, Sinaloa, Mexico
}

\begin{abstract}
Background: The COVID-19 pandemic is the most significant current public health crisis. Methods: We conducted a retrospective case series, including patients under 18 years of age admitted to respiratory triage and hospitalized with COVID-19 infection in two hospital centers. Epidemiological, clinical, laboratory and radiological findings were documented. The diagnosis of COVID-19 was confirmed by real-time reverse transcription-polymerase chain reaction (RT-PCR). For the analysis, patients were classified into three groups: no comorbidities, immunocompromised, and with chronic disease. Results: Fifty-four patients with COVID-19 were identified: 40 (74.1\%) were admitted through respiratory triage. Of these, 28 (70\%) were hospitalized, and 14 (25.9\%) were already in the hospital. In addition, 26 (48.1\%) presented comorbidities. A mild clinical course was observed in 14 cases (53.7\%). The mean age was 6 years, with an interquartile range from 11 months to 13 years. The male sex was more frequent, representing $59.3 \%$. Fever was the most common symptom in $74 \%$ of the patients. Lymphopenia was observed in $28.6 \%$, and $69.3 \%$ had elevated C-reactive protein. Ground glass injuries were documented in $30.9 \%$ of COVID-19 cases; $11.1 \%$ of the patients required mechanical ventilation and vasopressor treatment. Conclusions: Fever was the main symptom, and mild infection was the principal presentation. In hospitalized patients with some comorbidity and COVID-19, the disease was more severe, with a high percentage of mortality.
\end{abstract}

Keywords: COVID-19. Clinical features. Computed tomography. Children.

\section{Características clínicas y epidemiológicas de la COVID-19 en niños: experiencia en dos centros hospitalarios}

\section{Resumen}

Introducción: La pandemia de COVID-19 es la mayor crisis de salud pública actual. Métodos: Análisis de una serie de casos retrospectiva de pacientes menores de 18 años que ingresaron al triaje respiratorio y de pacientes hospitalizados con COVID-19 en dos centros hospitalarios. Se registraron variables epidemiológicas, clínicas, de laboratorio y radiológicas.

\section{Correspondence:}

*Jesús J. Martínez-García

E-mail: jjmtz64@ hotmail.com
Available online: 16-12-2021

Date of reception: $13-08-2020$

Date of acceptance: 29-08-2021

DOI: $10.24875 /$ BMHIM.20000250
Bol Med Hosp Infant Mex. 2021;78(6):506-514

www.bmhim.com

1665-1146/C 2021 Hospital Infantil de México Federico Gómez. Published by Permanyer. This is an open access article under the CC BY-NC-ND license (http://creativecommons.org/licenses/by-nc-nd/4.0/). 
El diagnóstico de COVID-19 fue confirmado por reacción en cadena de la polimerasa con transcriptasa inversa en tiempo real (RT-PCR). Para el análisis, los pacientes se clasificaron en tres grupos: sin comorbilidad, inmunocomprometidos y con enfermedad crónica. Resultados: Se identificaron 54 pacientes con COVID-19, de los cuales 40 (74.1\%) ingresaron por el triaje respiratorio y, de estos, 28 (70\%) fueron hospitalizados y 14 (25.9\%) ya estaban hospitalizados; 26 pacientes (48.1\%) presentaban comorbilidad. El curso clínico leve se observó con mayor frecuencia, en 14 casos (53.7\%). La mediana de edad fue de 6 años (rango intercuartílico: 11 meses a 13 años). El sexo masculino fue más frecuente, con el 59.3\%. La fiebre fue el síntoma más común, en el $74 \%$ de los pacientes. Se observó linfocitopenia en el $28.6 \%$ y y el $69.3 \%$ presentaron elevación de la proteína $C$ reactiva. Las lesiones en vidrio esmerilado se documentaron en el $30.9 \%$ de los casos y el $11.1 \%$ de los pacientes requirieron ventilación mecánica y tratamiento vasopresor. Conclusiones: La fiebre fue el síntoma principal y la presentación leve de la enfermedad fue la más frecuente. En los pacientes hospitalizados con alguna comorbilidad e infectados por COVID-19, la gravedad de la enfermedad fue mayor, con un alto porcentaje de mortalidad.

Palabras clave: COVID-19. Características clínicas. Tomografía computarizada. Niños.

\section{Introduction}

In December 2019, an "unexplained viral pneumonia" outbreak attributed to a new coronavirus (2019$\mathrm{nCoV}$ ) appeared in Wuhan, Hubei Province, China ${ }^{1,2}$. In February 2020, it was classified as severe acute respiratory syndrome coronavirus 2 (SARS-CoV-2) by the International Committee on Taxonomy of Viruses; subsequently, the World Health Organization (WHO) officially named this new disease as coronavirus disease 2019 (COVID-19) ${ }^{3,4}$. SARS-CoV-2 is highly contagious and caused a rapid spread of infection throughout China and the rest of the world ${ }^{5}$. The exponential increase in cases prompted WHO to classify this new disease as a public health emergency of international concern, declaring it a pandemic on March $11,2020^{6}$.

The main routes of transmission of COVID-19 in children are respiratory and close contact with symptomatic and asymptomatic family members ${ }^{7-9}$. So far, case reports in neonates are limited. Only case reports have been published in which vertical transmission has not been confirmed, so transmission of SARS-CoV-2 from mother to newborn is still inconclusive ${ }^{10-12}$. Children present with a milder form of the disease than adults. Asymptomatic infections and mild and moderate forms of the disease comprise more than $90 \%$ of the reported cases with a positive COVID-19 test in children ${ }^{13}$.

Severe and critical cases in children represent $5.9 \%$, compared to $18.5 \%$ in adults ${ }^{14}$. Some hypotheses have been proposed to explain the lower number of COVID19 infections in children:

1. A difference in the child's immune system compared to that of the adult, both in its composition and in its functional response capacity.

2. The presence of other viruses in the respiratory tract of children could limit the growth of SARS-CoV-2.
3. The difference in angiotensin-converting enzyme 2 (ACE-2) receptor expression, which is necessary for SARS-CoV-2 binding and infection ${ }^{15-17}$.

Fever and cough are the most common symptoms in children but occur less frequently than in adults. In general, compared with adults, the clinical expression in this population is modified because a large proportion of those infected is asymptomatic. In addition, laboratory and thoracic imaging findings may not be specific in children with COVID-198,19.

The objective of this case series was to describe the clinical and epidemiological characteristics, laboratory results, and tomographic findings of children under 18 years of age with confirmed COVID-19 in two hospital centers in Culiacán, Sinaloa, Mexico.

\section{Methods}

We conducted a retrospective cross-sectional study in two pediatric hospitals. All patients under 18 years of age with respiratory triage admission and patients hospitalized between April 1 and June 30, 2020, with a confirmatory COVID-19 test were included in the study. Samples were collected with nasopharyngeal swabs, and COVID-19 diagnosis was confirmed by quantitative real-time reverse transcriptase-polymerase chain reaction (RT-PCR) method at the Laboratorio Estatal de Salud Pública of Sinaloa (Sinaloa State Public Health Laboratory). Clinical, laboratory and radiographic data were extracted from the electronic clinical record and captured in a database. The study was approved by the Ethics and Research Committee of the hospitals that participated in the study: Hospital Pediátrico de Sinaloa Dr. Rigoberto Aguilar Pico (2020 HPS.DI.309) and Hospital General Regional No. 1, Instituto Mexicano de Seguro Social (2020-2506-037) in Culiacán, Sinaloa, México. 
Epidemiologic, clinical, laboratory, and radiologic findings were documented using chest computed tomography (CCT). Anthropometric variables were used to classify patients as underweight, normal, overweight, or obese. COVID-19 symptoms were recorded in all patients and classified according to symptomatology as upper respiratory tract infection (URTI) associated with the presence of odynophagia, rhinorrhea, and dry cough; or lower respiratory tract infection (LRTI), in patients with wet cough/rales, tachypnea, shortness of breath, dyspnea, and oxygen saturation less than $92 \%$. CCT findings were classified according to the consensus of the Radiological Society of North America (RSNA), the Society of Thoracic Radiology (STR), and the American College of Radiology (ACR) into four categories:

1. Typical pattern, characterized by ground-glass opacities (GGO) of bilateral and peripheral distribution, characteristic of COVID-19 viral pneumonia.

2. Indeterminate pattern, shows with multifocal, diffuse, perihilar, or unilateral GGO with or without condensation.

3. Atypical pattern, presents single lobar or segmental condensation without GGO, pulmonary cavitation, or pleural effusion.

4. Negative, absence of tomographic findings suggestive of pneumonia ${ }^{20,21}$.

Three groups were classified to compare factors that could increase the risk of mortality: patients without comorbidities, immunocompromised children (patients with cancer or chemotherapy treatment), and patients with chronic diseases (patients with medical pathology unrelated to immunodeficiency, with more than one year of evolution or with congenital disease and limitation in physical activity).

According to clinical, laboratory, and CCT findings, the severity of COVID-19 was classified as ${ }^{22}$ follows: mild (symptoms of acute URTI, negative CCT, no oxygen treatment); moderate (pneumonia diagnosed clinically or by imaging studies, fever, productive cough, wheezing, oxygen saturation of $95 \%$, and no need for supplemental oxygen); severe (fever and cough accompanied by gastrointestinal symptoms such as diarrhea, evolution of one week, dyspnea, central cyanosis and saturation below $92 \%$, and need for noninvasive supplemental therapy and treatment with inotropic or vasopressors); or critical (rapid progression to acute respiratory distress syndrome (ARDS) or respiratory failure, shock, encephalopathy, heart failure, disseminated intravascular coagulation, acute kidney injury, multiple organ failure, and need for oxygen with mechanical ventilation and support with inotropic and vasopressors).

Laboratory findings were defined as follows: leukopenia $\left(<5.5 \times 10^{9} / L\right)$, neutropenia $\left(<1.0 \times 10^{9} / L\right)$, lymphopenia $\left(<1.2 \times 10^{9} / \mathrm{L}\right)$, thrombocytopenia $(<150 \times$ $109 / \mathrm{L}$ ), elevated C-reactive protein ( $>3 \mathrm{mg} / \mathrm{dL}$ ), elevated aspartate and alanine aminotransferase (> $50 \mathrm{U} / \mathrm{L})$.

\section{Statistical analysis}

When appropriate, continuous variables were expressed as means or medians and standard deviation or interquartile ranges (IQR). Categorical variables were summarized as absolute values and percentages. The Mann-Whitney U-test was used to compare epidemiological variables and categorical clinical variables. A $p$-value $<0.05$ was considered as significant. We used the SPSS version 22.0 statistical package.

\section{Results}

Between April 1 and June 30, 2020, 54 children with confirmed RT-PCR for COVID-19 were identified. The first case occurred in an 8-month-old infant with Down syndrome (April 15, 2020). Figure 1 shows the distribution of the 54 patients with COVID-19 by week and severity of infection. Forty patients $(74.1 \%)$ were admitted through respiratory triage, of whom $28(70 \%)$ were hospitalized, and the remaining patients (12) were discharged home with symptomatic treatment. Fourteen patients $(25.9 \%)$ were already hospitalized for another disease; 28 patients (51.9\%) were classified as having no comorbidities, $14(25.9 \%)$ with immunodeficiency, and $12(22.2 \%)$ with chronic disease. According to the severity of infection, 29 patients $(53.7 \%)$ had mild, $14(25.9 \%)$ moderate, $5(9.3 \%)$ severe, and $6(11.1 \%)$ critical disease.

Figure 2 shows the distribution of COVID-19 cases with no comorbidities, immunocompromised, with chronic diseases according to the severity of the disease.

Table 1 summarizes the clinical characteristics of the 54 patients with COVID-19. In the group of patients with no comorbidities, the median age was 5 years (IQR 9 months-12.7 years); in immunocompromised children, the median age was 9 years (IQR 1.7-16 years); in children with chronic diseases, the median age was 5.5 years (IQR 6 months-12.5 years, $p=0.314$ ). The most frequent age group was 1-5 years, with 14 cases $(25.9 \%)$. 


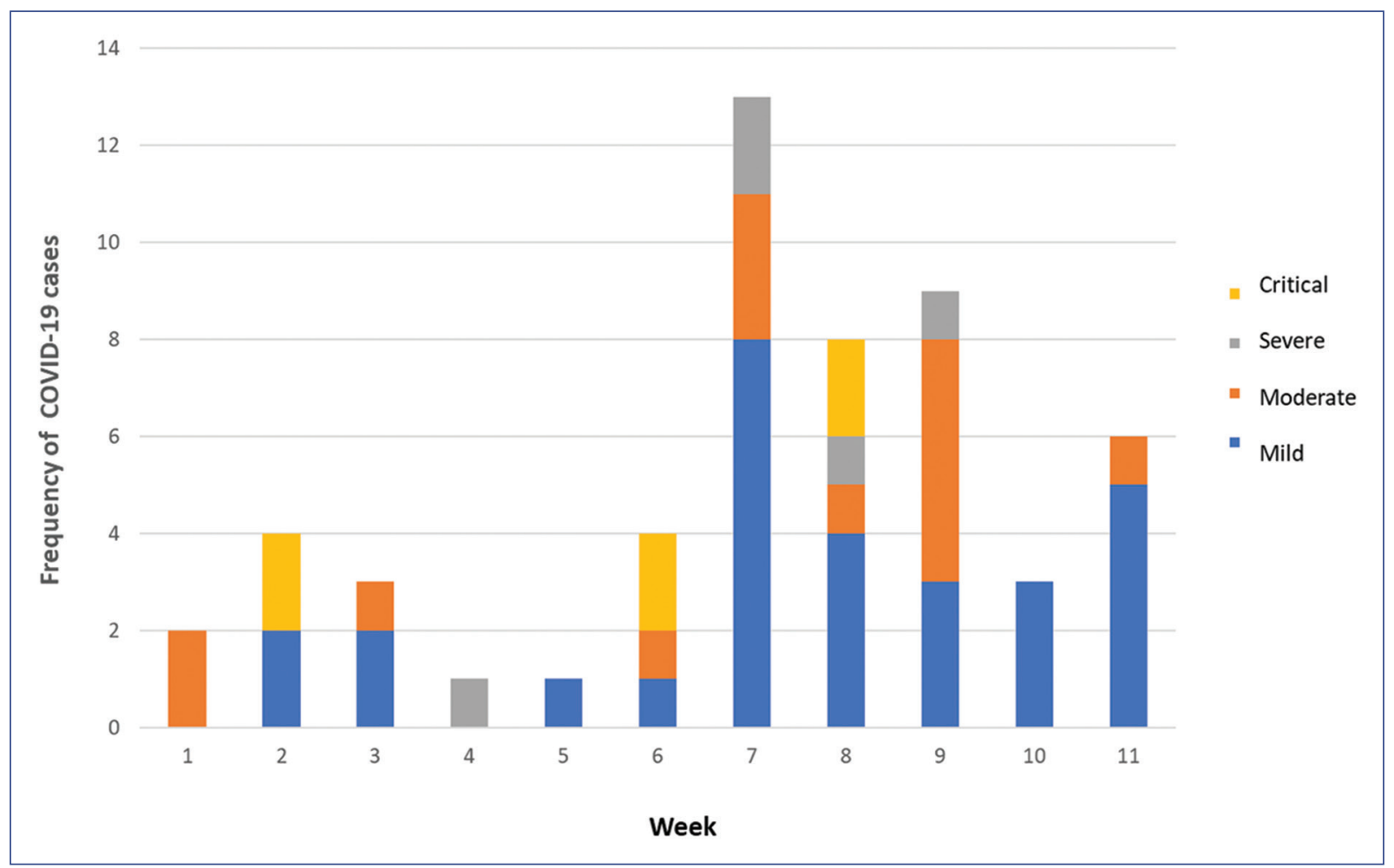

Figure 1. Distribution of patients with COVID-19 ( $N=54$ ) by week (April 1 to June 30,2020 ) and severity of infection.

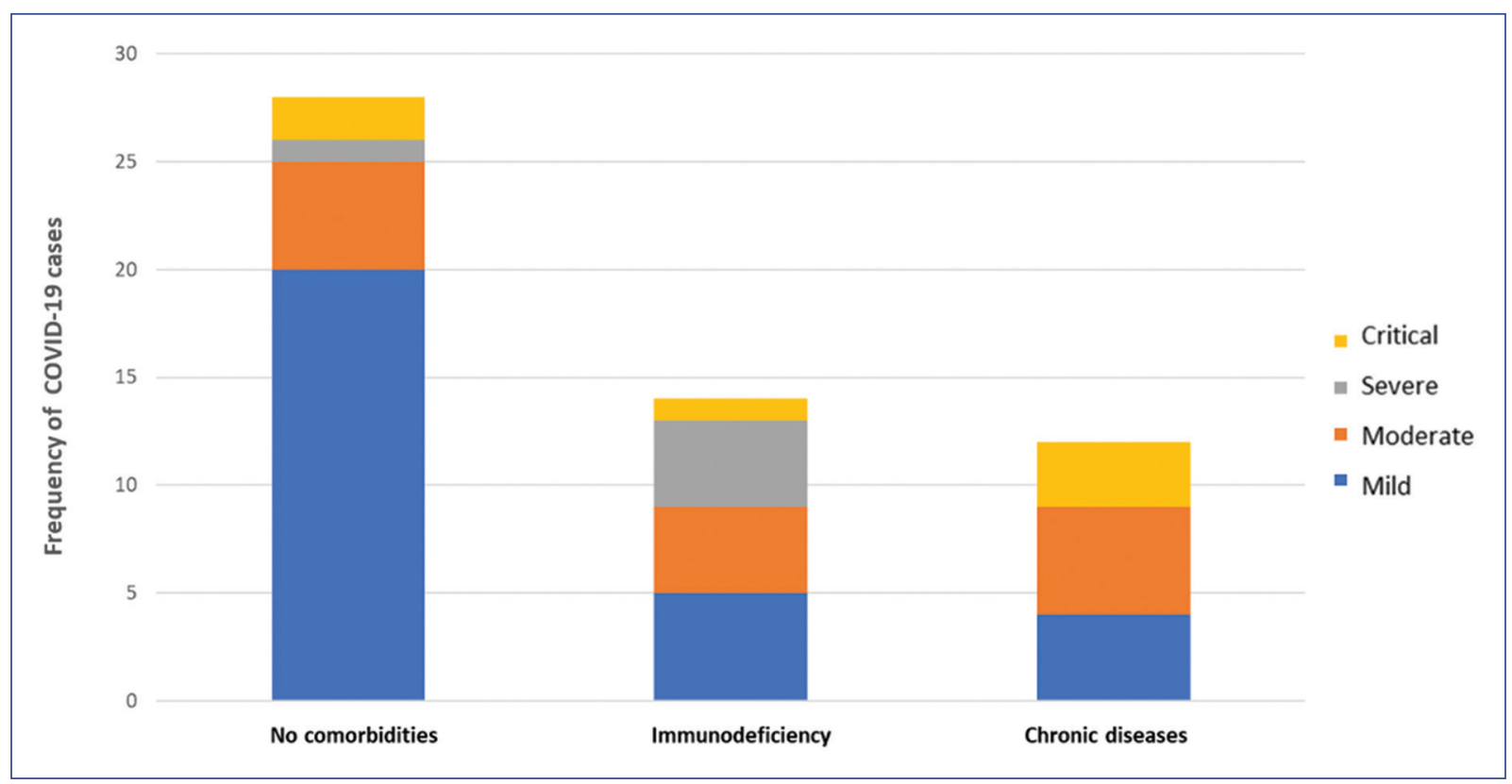

Figure 2. Distribution of the 54 cases with COVID-19 by medical history and disease severity.

Figure 3 describes the distribution of COVID-19 cases by age group and disease severity. The distribution by sex was higher in males, with 32 cases $(59.3 \%$; $p=0.672)$. According to weight, 35 patients $(64.8 \%)$ were of normal weight. The route of infection in 30 patients $(55.6 \%)$ was by contact with a non-relative 
Table 1. Clinical and epidemiological characteristics of children with COVID-19

\begin{tabular}{|c|c|c|c|c|c|}
\hline Characteristics & $\begin{array}{c}\text { Total } \\
(n=54)\end{array}$ & $\begin{array}{l}\text { No CM } \\
(n=28)\end{array}$ & $\begin{array}{c}\text { IC } \\
(n=14)\end{array}$ & $\begin{array}{c}C D \\
(n=12)\end{array}$ & $p$-values \\
\hline Age (years) ${ }^{*}$ & $6(11 \mathrm{~m}-13)$ & $5(9 \mathrm{~m}-12.7)$ & $9(1.7-16)$ & $5.5(6 \mathrm{~m}-12.5)$ & 0.314 \\
\hline $\begin{array}{l}\text { Age groups (years) } \\
<1 \\
1-5 \\
6-10 \\
11-15 \\
>15\end{array}$ & $\begin{array}{l}13(24.1) \\
14(25.9) \\
8(14.8) \\
13(24.1) \\
6(11.1)\end{array}$ & $\begin{array}{l}7(25) \\
9(32.1) \\
3(10.7) \\
7(25) \\
2(7.1)\end{array}$ & $\begin{array}{l}3(21.4) \\
2(14.3) \\
3(21.4) \\
2(14.3) \\
4(28.6)\end{array}$ & $\begin{array}{c}3(25) \\
3(25) \\
2(16.7) \\
4(33.3) \\
0(0)\end{array}$ & 0.383 \\
\hline $\begin{array}{l}\text { Sex } \\
\text { Female } \\
\text { Male }\end{array}$ & $\begin{array}{l}22(40.7) \\
32(59.2)\end{array}$ & $\begin{array}{l}10(35.7) \\
18(64.2)\end{array}$ & $\begin{array}{l}7(50) \\
7(50)\end{array}$ & $\begin{array}{l}5(41.5) \\
7(58.3)\end{array}$ & 0.672 \\
\hline $\begin{array}{l}\text { Status by weight } \\
\text { Normal } \\
\text { Underweight } \\
\text { Overweight } \\
\text { Obesity }\end{array}$ & $\begin{array}{l}35(64.8) \\
7(13) \\
2(7.1) \\
2(7.1)\end{array}$ & $\begin{aligned} 22 & (78.6) \\
2 & (7.1) \\
2 & (7.1) \\
2 & (7.1)\end{aligned}$ & $\begin{array}{l}6(42.9) \\
2(14.3) \\
4(28.6) \\
2(14.6)\end{array}$ & $\begin{array}{l}7(58.3) \\
3(25) \\
2(16.7) \\
0(0)\end{array}$ & 0.189 \\
\hline $\begin{array}{l}\text { Route of infection } \\
\text { Contact with an infected family member } \\
\text { Contact with a non-relative infected individual } \\
\text { In-hospital }\end{array}$ & $\begin{array}{l}10(18.5) \\
30(55.6) \\
14(25.9)\end{array}$ & $\begin{array}{c}9(32.1) \\
16(57.1) \\
3(10.7)\end{array}$ & $\begin{array}{c}0(0) \\
8(57.1) \\
6(42.9)\end{array}$ & $\begin{array}{c}1(8.3) \\
6(50) \\
5(41.7)\end{array}$ & 0.023 \\
\hline $\begin{array}{l}\text { COVID-19 severity } \\
\text { Mild } \\
\text { Moderate } \\
\text { Severe } \\
\text { Critical }\end{array}$ & $\begin{array}{c}29(53.7) \\
14(25.9) \\
5(9.3) \\
6(11.1)\end{array}$ & $\begin{array}{l}20(71.7) \\
5(17.9) \\
1(3.6) \\
2(7.1)\end{array}$ & $\begin{array}{c}5(35.7) \\
4(28.6) \\
4(28.6) \\
1(7.1)\end{array}$ & $\begin{array}{c}4(33.3) \\
5(41.7) \\
0(0) \\
3(25)\end{array}$ & 0.010 \\
\hline $\begin{array}{l}\text { Signs and symptoms } \\
\text { Body temperature } \\
<37.5^{\circ} \mathrm{C} \\
37.5-38^{\circ} \mathrm{C} \\
38.1-39^{\circ} \mathrm{C} \\
>39^{\circ} \mathrm{C}\end{array}$ & $\begin{array}{c}14(25.9) \\
9(16.7) \\
17(31.5) \\
14(25.9)\end{array}$ & $\begin{array}{l}10(35.7) \\
5(17.9) \\
5(17.9) \\
8(28.6)\end{array}$ & $\begin{array}{l}1(7.1) \\
3(21.4) \\
6(42.9) \\
4(28.6)\end{array}$ & $\begin{array}{c}3(25) \\
1(8.3) \\
6(50) \\
2(16.7)\end{array}$ & 0.261 \\
\hline $\begin{array}{l}\text { Symptoms of URTI } \\
\text { Rhinorrhea/nasal congestion } \\
\text { Odynophagia } \\
\text { Dry cough }\end{array}$ & $\begin{array}{l}16(29.6) \\
6(11.1) \\
24(44.4)\end{array}$ & $\begin{array}{c}10(35.7) \\
3(10.7) \\
12(42.9)\end{array}$ & $\begin{array}{l}3(21.4) \\
2(14.3) \\
5(35.7)\end{array}$ & $\begin{array}{l}3(25) \\
1(8.3) \\
7(58.3)\end{array}$ & $\begin{array}{l}0.585 \\
0.886 \\
0.497\end{array}$ \\
\hline $\begin{array}{l}\text { Symptoms of LRTI } \\
\text { Wet cough/rales } \\
\text { Tachypnea } \\
\text { Respiratory distress } \\
\text { Oxygen saturation }<92 \% \\
\text { Dyspnea }\end{array}$ & $\begin{array}{l}22(40.7) \\
17(31.5) \\
19(36.5) \\
17(31.5) \\
11(20.4)\end{array}$ & $\begin{array}{l}11(39.3) \\
10(35.7) \\
6(23.1) \\
6(21.4) \\
2(7.1)\end{array}$ & $\begin{array}{l}4(28.6) \\
1(7.1) \\
4(28.6) \\
4(28.6) \\
5(35.7)\end{array}$ & $\begin{array}{l}7(58.3) \\
6(50) \\
9(75) \\
7(58.3) \\
4(33.3)\end{array}$ & $\begin{array}{c}0.298 \\
0.05 \\
0.007 \\
0.068 \\
0.043\end{array}$ \\
\hline $\begin{array}{l}\text { Gastrointestinal symptoms } \\
\text { Abdominal pain } \\
\text { Hyporexia/anorexia } \\
\text { Nausea } \\
\text { Vomiting } \\
\text { Diarrhea }\end{array}$ & $\begin{array}{c}8(14.8) \\
14(25.9) \\
9(16.7) \\
10(18.5) \\
6(11.6)\end{array}$ & $\begin{array}{l}4(14.3) \\
6(21.4) \\
4(14.3) \\
5(17.9) \\
4(14.3)\end{array}$ & $\begin{array}{l}3(21.4) \\
4(28.6) \\
2(14.3) \\
2(14.3) \\
1(7.1)\end{array}$ & $\begin{array}{c}1(8.3) \\
4(33.3) \\
3(23) \\
3(25) \\
1(8.3)\end{array}$ & $\begin{array}{l}0.641 \\
0.709 \\
0.680 \\
0.776 \\
0.740\end{array}$ \\
\hline $\begin{array}{l}\text { Neurological symptoms } \\
\text { Headache } \\
\text { Seizures } \\
\text { Anosmia } \\
\text { Dysgeusia } \\
\text { Asthenia } \\
\text { Myalgia or muscle fatigue } \\
\text { Chest pain } \\
\text { Skin rash }\end{array}$ & $\begin{array}{c}14(25.9) \\
2(3.7) \\
1(1.9) \\
1(1.9) \\
20(37) \\
5(9.3) \\
5(9.3) \\
3(5.6)\end{array}$ & $\begin{array}{c}8(28.6) \\
0(0) \\
1(3.6) \\
1(3.6) \\
7(25) \\
1(3.6) \\
2(7.1) \\
3(10.7)\end{array}$ & $\begin{array}{c}6(42.9) \\
1(7.1) \\
0(0) \\
0(0) \\
8(57.1) \\
4(28.6) \\
1(7.1) \\
0(0)\end{array}$ & $\begin{array}{c}0(0) \\
1(8.3) \\
0(0) \\
0(0) \\
5(41.7) \\
0(0) \\
2(16.7) \\
0(0)\end{array}$ & $\begin{array}{l}0.041 \\
0.323 \\
0.623 \\
0.623 \\
0.118 \\
0.014 \\
0.604 \\
0.229\end{array}$ \\
\hline
\end{tabular}




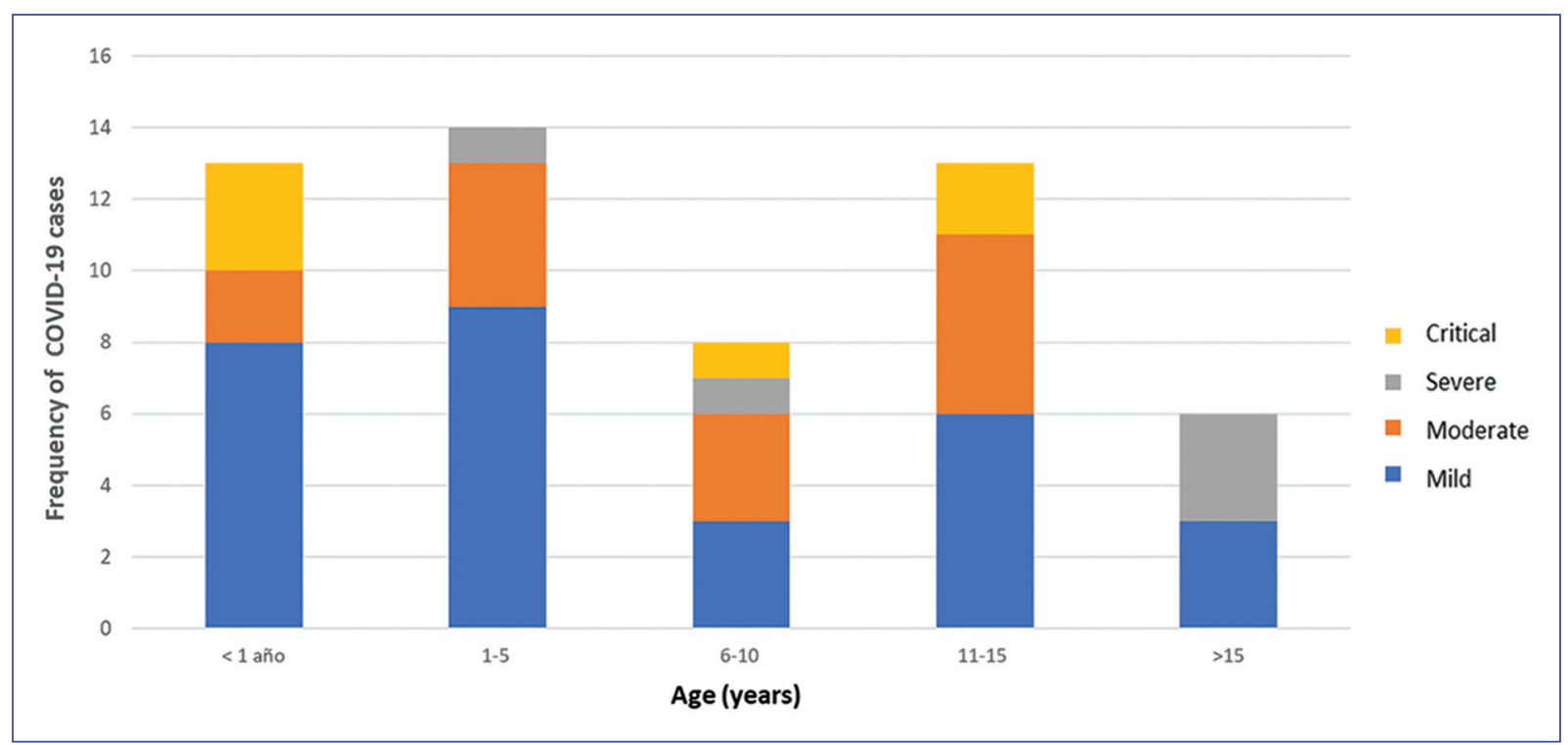

Figure 3. Distribution of the 54 cases with COVID-19 by age group and disease severity.

infected individual; the in-hospital route of infection was high in patients with some immunodeficiency $(6,42.9 \%)$ or chronic disease $(5,41.7 \% ; p=0.023)$. Fever was the most frequent symptom observed in 40 patients (74.1\%).

In patients with URTI, dry cough was reported in $24(44.4 \%)$ and rhinorrhea with nasal congestion in 16 cases (29.6\%); no significant differences were observed between the study groups. In children with LRTI, wet cough with rales was the most frequent symptom in 22 cases $(40.7 \%)$. In patients with chronic diseases, respiratory distress was the most frequent sign in nine cases (75\%; $p=0.007)$. In 17 cases $(31.5 \%)$, oxygen saturation was $<92 \%$. Hyporexia was the most frequent gastrointestinal symptom in 14 patients $(25.9 \%)$. In addition, other symptoms were recorded, such as vomiting $(n=10,18.5 \%)$ and diarrhea $(n=6,11.6 \%)$. Headache was the most prevalent neurological symptom, detected in 14 cases (25.9\%); the least frequent were seizures $(n=2,3.7 \%)$, anosmia, and dysgeusia in one case (1.9\%), respectively. Among the general symptoms, general malaise was recorded in $20(37 \%)$, myalgia or muscle fatigue in $5(9.3 \%)$, chest pain in $5(9.3 \%)$, and skin rash in 3 patients (5.6\%).

Table 2 summarizes the laboratory and CCT characteristics observed in the $42 / 54(77.8 \%)$ patients with COVID-19 who were hospitalized after respiratory triage or who presented with COVID-19 while hospitalized. Leukopenia ( $<5500$ total leukocytes) was observed in 9 patients (21.4\%), neutropenia $(<1000$ absolute neutrophils) in 9 (21.4\%), lymphopenia ( $<1200$ absolute lymphocytes) in $12(28.6 \%)$, and thrombocytopenia $(<150,000 \mathrm{~mL})$ in $14(33.3 \%)$ patients. All alterations were observed more frequently in immunocompromised patients. C-reactive protein (CRP) levels $>3 \mathrm{mg} / \mathrm{L}$ were observed in $69.5 \%$ (16/23), and serum alanine and aspartate aminotransferase (ALT and AST) levels > $50 \mathrm{U} / \mathrm{L}$ were recorded in $61.5 \%(16 / 26)$, respectively.

The alterations observed in 42 CCT scans were heterogeneous. Thirteen patients $(31 \%)$ showed typical COVID-19 (GGO) images, 14 (33\%) showed an intermediate pattern, six (14.3\%) atypical pattern, and nine (21.4\%) patients had negative or normal CCT scans.

Thirty-nine patients $(92.9 \%)$ received antibiotic treatment, $32(76.2 \%)$ with antivirals, and $21(50 \%)$ with hydroxychloroquine. Six patients $(14.2 \%)$ required respiratory support with mechanical ventilation and vasopressor drugs.

The median in-hospital days was 10 days (IQR 7-24 days), and $3 / 42$ (7.1\%) patients were still hospitalized at the end of the study.

Comorbidities were reported in $26(61.9 \%)$ patients, and $6(14.2 \%)$ deaths were recorded. In the group of patients with immunodeficiency, one death was recorded in a 6-year-old female patient with Down syndrome and acute lymphoblastic leukemia. In contrast, five deaths were recorded in the group of patients with chronic disease: an 8-month-old male with congenital heart disease and Down syndrome, an 8-year-old male 
Tabla 2. Laboratory and CCT results of children hospitalized with COVID-19

\begin{tabular}{|c|c|c|c|c|c|}
\hline Characteristics & $\begin{array}{l}\text { Total } \\
(\mathrm{n}=42)\end{array}$ & $\begin{array}{l}\text { No CM } \\
(n=16)\end{array}$ & $\begin{array}{c}\text { IC } \\
(n=14)\end{array}$ & $\begin{array}{c}\text { CD } \\
(n=12)\end{array}$ & $p$-values \\
\hline $\begin{array}{l}\text { Initial results } \\
\text { Leukocytes } \times 10^{9} / \mathrm{L}^{*} \\
\text { Leukopenia }<5.5 \times 10^{9} / \mathrm{L} \\
\text { Neutropenia }<1.0 \times 10^{9} / \mathrm{L} \\
\text { Lymphopenia }<1.2 \times 10^{9} / \mathrm{L} \\
\text { Thrombocytopenia }<150 \\
\text { CRP }>3 \mathrm{mg} / \mathrm{dL} \\
\text { ALT }>50 \mathrm{U} / \mathrm{L} \\
\text { AST }>50 \mathrm{U} / \mathrm{L}\end{array}$ & $\begin{array}{c}9(21.4) \\
9(21.4) \\
12(28.6) \\
14(33.3) \\
16 / 23(69.5) \\
16 / 26(61.5) \\
16 / 26(61.5)\end{array}$ & $\begin{array}{c}13.8(8.3-21.3) \\
2(12.5) \\
1(6.3) \\
1(6.3) \\
3(18.7) \\
5 / 8(62.5) \\
4 / 8(50.0) \\
4 / 8(50.0)\end{array}$ & $\begin{array}{l}3.5(0.2-11.2) \\
6(42.8) \\
7(50) \\
8(57) \\
9(64.3) \\
6 / 8(75) \\
8 / 11(72.7) \\
8 / 11(72.7)\end{array}$ & $\begin{array}{c}10.4(8.8-14.3) \\
1(8.3) \\
1(8.3) \\
3(25) \\
2(16.7) \\
5 / 7(71.4) \\
4 / 7(57.1) \\
4 / 7(57.1)\end{array}$ & $\begin{array}{l}0.021 \\
0.032 \\
0.003 \\
0.004 \\
0.004 \\
0.856 \\
0.580 \\
0.580\end{array}$ \\
\hline $\begin{array}{l}\text { CCT, according to RSNA } \\
\text { Typical } \\
\text { Indeterminate } \\
\text { Atypical } \\
\text { Negative }\end{array}$ & $\begin{array}{c}13(30.9) \\
14(33.3) \\
6(14.2) \\
9(21.4)\end{array}$ & $\begin{array}{l}4(25.0) \\
4(25.0) \\
1(6.25) \\
7(43.7)\end{array}$ & $\begin{array}{c}7(50) \\
4(28.6) \\
2(14.3) \\
1(7.1)\end{array}$ & $\begin{array}{c}2(16.7) \\
6(50.0) \\
3(25.0) \\
1(8.3)\end{array}$ & 0.087 \\
\hline $\begin{array}{l}\text { Treatment } \\
\text { Antibiotic } \\
\text { Antiviral } \\
\text { Hydroxychloroquine } \\
\text { Mechanical ventilation } \\
\text { Vasopressor/inothropic } \\
\text { Days of hospitalization* } \\
\text { Mortality }\end{array}$ & $\begin{array}{c}39(92.9) \\
32(76.2) \\
21(50) \\
6(14.1) \\
6(14.1) \\
10(7-24) \\
6(14.2)\end{array}$ & $\begin{array}{c}15(93.8) \\
12(75) \\
7(43.8) \\
0(0) \\
0(0) \\
12(5-17) \\
0(0)\end{array}$ & $\begin{array}{c}13(92.9) \\
12(85.7) \\
9(64.3) \\
1(7.1) \\
1(7.1) \\
19(8-32) \\
1(7.1)\end{array}$ & $\begin{array}{c}11(91.7) \\
7(58.3) \\
5(41.7) \\
5(41.7) \\
5(41.7) \\
22(7-30) \\
5(41.7)\end{array}$ & $\begin{array}{l}0.537 \\
0.256 \\
0.372 \\
0.005 \\
0.005 \\
0.186 \\
0.005\end{array}$ \\
\hline
\end{tabular}

Data are expressed as $n(\%)$ unless indicated otherwise.

* median (interquartile range).

ALT, alanine aminotransferase; AST, aspartate aminotransferase; CCT, chest computed tomography; CD, chronic diseases; CM, comorbidities; COVID-19, coronavirus disease 2019; IC, immunocompromise; IQR, interquartile range; LRTI, lower respiratory tract infection; RSNA, Radiological Society of North America; URTI, upper respiratory tract infection.

with muscular atrophy and chronic lung disease, an 11-year-old male with chronic lung disease and chronic renal failure, a 13-year-old female patient with Turner syndrome and chronic renal failure, and a 14-year-old male with infantile cerebral palsy and chronic lung disease. All patients were treated with vasoactive amines and mechanical ventilation support.

\section{Discussion}

This case series describes the spectrum of illness produced by SARS-CoV-2 infection in 54 children during the first three months of the pandemic. The description of this series is based on the experience gained from caring for a group of 54 children with COVID-19. Unfortunately, it was not possible to detect asymptomatic infections because RT-PCR was only performed in children admitted with suspected COVID19 due to their symptoms. However, we know the potential risk of transmission in asymptomatic patients and the importance of developing pandemic control measures. The relevance of our study is that it describes the experience in two hospitals in a considerable sample of COVID-19 cases representing clinical, laboratory, radiological, treatment, and mortality variables. In our study, the in-hospital transmission of COVID-19 was high, and the transmission source was probably the patients' relatives or healthcare personnel. In a series of 130 pediatric patients, Parri et al. ${ }^{23}$ observed that $53.8 \%$ of the positive cases had contact with a COVID19 case, and $95.5 \%$ was a family member.

In our study, the group aged 1 to 5 years had the highest prevalence of COVID-19 and a higher frequency in males. According to disease severity, the group with mild symptoms was the most frequent. The results are similar to the report of 31 cases of COVID19 by Wang et al. ${ }^{24}$, which was one of the first studies reported in China. In that report, the average age of the 31 children studied was 7 years. Sixty-eight percent of the cases had contact with confirmed infected adults. The clinical classification was asymptomatic in $13 \%$, mild in $42 \%$ of the cases, and moderate in $45 \%$; the male sex was the most frequent, and no severe or critical cases were observed ${ }^{24}$.

The most frequent clinical data in our study were fever $>38^{\circ} \mathrm{C}$, dry or wet cough, hyporexia, and headache. The results of a systematic review by De Souza et al. ${ }^{25}$ described the clinical laboratory and radiological 
characteristics of 1124 cases of children with COVID-19 obtained from 38 case series. Fever was the most prevalent symptom, followed by cough, nasal symptoms, diarrhea, nausea, vomiting, fatigue, and respiratory distress.

In another study, Kainth et al. ${ }^{26}$ described the clinical characteristics, sociodemographics, hospital course, and disease severity of 65 patients with COVID-19 in the USA. In this series, fever was present in $86 \%$ of patients, lower respiratory symptoms or signs in $60 \%$, and gastrointestinal symptoms in $62 \%$. Intensive care was required in $35 \%$ of patients.

Laboratory tests alterations observed in our study were leukopenia, neutropenia, lymphopenia, thrombocytopenia, and increased liver enzymes. The results were similar to those reported by Parri et al. ${ }^{23}$, who detected leukopenia and lymphopenia in $36.8 \%$ and $15.7 \%$ of patients, respectively, while increases in ALT and AST were recorded in $18.3 \%$ and $11.8 \%$, respectively.

The limitations of this study include those inherent to the case series design, which only describes the clinical characteristics of a group of patients without allowing statistical inferences or causal associations. In addition, the magnitude of the problem was unknown because the results of laboratory tests and imaging studies were only performed in patients with symptoms who attended the hospitals. However, we consider the results obtained from the sample studied to be of great interest because they describe the first cases of COVID-19 in two hospitals with the highest concentration of pediatric population in Sinaloa.

In our study, during the first three months of the pandemic, a high percentage of children became infected with SARS-CoV-2 through contact with infected persons who were not immediate family members; infection was primarily mild, and fever was the main symptom. Conversely, the disease was more severe in patients hospitalized for chronic disease and infected with COVID-19, with a high mortality rate.

Fever is one of the leading causes of consultation to the pediatrician; therefore, pediatricians must have a high level of clinical suspicion to make a timely diagnosis of COVID-19.

\section{Ethical disclosures}

Protection of human and animal subjects. The authors declare that no experiments were performed on humans or animals for this study.

Confidentiality of data. The authors declare that they have followed the protocols of their work center on the publication of patient data.
Right to privacy and informed consent. The authors have obtained the written informed consent of the patients or subjects mentioned in the article. The corresponding author has this document.

\section{Conflicts of interest}

The authors declare no conflict of interest.

\section{Funding}

None.

\section{Acknowledgments}

We are thankful to the staff of the Laboratorio Estatal de Salud Pública de Sinaloa and the resident physicians of the Hospital Pediátrico de Sinaloa Dr. Rigoberto Aguilar Pico.

\section{References}

1. Singhal T. A review of coronavirus disease-2019 (COVID-19). Indian J Pediatr. 2020;87:281-6.

2. Huang C, Wang Y, Li X, Ren L, Zhao J, Hu Y, et al. Clinical features of patients infected with 2019 novel coronavirus in Wuhan, China. Lancet. 2020;395:497-506

3. Sankar J, Dhochak N, Kabra SK, Lodha R. COVID-19 in children: clinical approach and management. Indian J Pediatr. 2020;87:433-42.

4. World Health Organization. Coronavirus disease (COVID-19) outbreak. Geneva: WHO; 2020. Available from: https://www.who.int/emergencies/ diseases/novel-coronavirus-2019

5. World Health Organization. Novel coronavirus (COVID-19) situation. Geneva: World Health Organization; 2020. Available from: https://covid19. who.int

6. Chen N, Zhou M, Dong X, Qu J, Gong F, Han Y, et al. Epidemiological and clinical characteristics of 99 cases of 2019 novel coronavirus pneumonia in Wuhan, China: a descriptive study. Lancet. 2020;395:507-13.

7. Dong $\mathrm{Y}, \mathrm{Mo} X, \mathrm{Hu} \mathrm{Y}, \mathrm{Qi} X$, Jiang $\mathrm{F}$, Jiang Z, et al. Epidemiology of COVID-19 among children in China. Pediatrics. 2020;145:e20200702.

8. Zhang C, Gu J, Chen Q, Deng N, Li J, Huang L, et al. Clinical and epidemiological characteristics of pediatric SARS-CoV-2 infections in China: a multicenter case series. PLoS Med. 2020;17:e1003130.

9. Zimmermann P, Curtis N. Coronavirus infections in children including COVID-19: an overview of the epidemiology, clinical features, diagnosis, treatment and prevention options in children. Pediatr Infect Dis J. 2020;39:355-68.

10. Liu W, Wang J, Li W, Zhou Z, Liu S, Rong Z. Clinical characteristics of 19 neonates born to mothers with COVID-19. Front Med. 2020;14:193-8.

11. Zimmermann P, Curtis N. COVID-19 in children, pregnancy and neonates: a review of epidemiologic and clinical features. Pediatr Infect Dis J. 2020;39:469-77.

12. Lu Q, Shi Y. Coronavirus disease (COVID-19) and neonate: what neonatologist need to know. J Med Virol. 2020;92:564-7.

13. Brodin P. Why is COVID-19 so mild in children? Acta Paediatr. 2020;109:1082-3.

14. Children may be less affected than adults by novel coronavirus (COVID-19). Edited by Craig Mellis. J Paediatr Child Health. 2020;56:657.

15. Balasubramanian S, Rao NM, Goenka A, Roderick M, Ramanan AV. Coronavirus disease 2019 (COVID-19) in children-what we know so far and what we do not. Indian Pediatr. 2020;57:435-42.

16. Lu Y, Wen H, Rong D, Zhou Z, Liu H. Clinical characteristics and radiological features of children infected with the 2019 novel coronavirus. Clin Radiol. 2020;75:520-5.

17. Xia W, Shao J, Guo Y, Peng X, Li Z, Hu D. Clinical and CT features in pediatric patients with COVID-19 infection: different points from adults. Pediatr Pulmonol. 2020;55:1169-74.

18. Castillo AF, Bazaes ND, Huete GÁ. Radiología en la pandemia COVID-19: uso actual, recomendaciones para la estructuración del informe radiológico y experiencia de nuestro departamento. Rev Chil Radiol. 2020;26:88-99. 
Bol Med Hosp Infant Mex. 2021;78(6)

19. Simpson S, Kay FU, Abbara S, Bhalla S, Chung JH, Chung M, et al. Radiological Society of North America Expert Consensus Statement on reporting chest CT findings related to COVID-19: endorsed by the Society of Thoracic Radiology, the American College of Radiology, and RSNA Radiol Cardiothorac Imaging. 2020;2:e200152.

20. Liguoro I, Pilotto C, Bonanni M, Ferrari ME, Pusiol A, Nocerino A, et al. SARS-CoV-2 infection in children and newborns: a systematic review. Eur J Pediatr. 2020;179:1029-46.

21. Li Y, Guo F, Cao Y, Li L, Guo Y. Insight into COVID-2019 for pediatricians. Pediatr Pulmonol. 2020;55:E1-4.

22. Shen KL, Yang YH, Jiang RM, Wang TY, Zhao DC, Jiang Y, et al. Updated diagnosis, treatment and prevention of COVID-19 in children: experts' consensus statement (condensed version of the second edition) World J Pediatr. 2020;16:232-9.
23. Parri N, Magistà AM, Marchetti F, Cantoni B, Arrighini A, Romanengo M, et al. Characteristic of COVID-19 infection in pediatric patients: early findings from two Italian pediatric research networks. Eur J Pediatr. 2020:179:1315-23

24. Wang D, Ju XL, Xie F, Lu Y, Li FY, Huang HH, et al. [Clinical analysis of 31 cases of 2019 novel coronavirus infection in children from six provinces (autonomous region) of northern China]. Zhonghua $\mathrm{Er} \mathrm{Ke} \mathrm{Za}$ Zhi. 2020;58(4):269-74. Chinese.

25. De Souza TH, Nadal JA, Nogueira RJN, Pereira RM, Brandão MB. Clinical manifestations of children with COVID-19: a systematic review. Pediatr Pulmonol. 2020;55:1892-9.

26. Kainth MK, Goenka PK, Williamson KA, Fishbein JS, Subramony A, Barone S, et al. Early experience of COVID-19 in a US Children's Hospital. Pediatrics. 2020;146:e2020003186. 